\title{
Native roadside perennial grasses persist a decade after planting in the Sacramento Valley
}

\author{
by Ryan E. O'Dell, Stephen L. Young \\ and Victor P. Claassen
}

\section{Restoring native grassland along} roadsides can provide a relatively low-maintenance, drought-tolerant and stable perennial vegetative cover with reduced weed growth, as opposed to the high-maintenance invasive annual cover (requiring intensive mowing and herbicide treatments) that dominates most Sacramento Valley roadsides. A survey of longestablished roadside native-grass plantings in Yolo County showed that once established and protected from disturbance, such plantings can persist with minimal maintenance for more than a decade, retaining a high proportion of native species. The survey also showed that each species of native perennial grass displays a microhabitat preference for particular roadside topographic positions, and that native perennial grass cover is negatively affected by disturbance.
$G$ rasslands cover approximately $17 \%$ (almost 20 million acres) of California's landscape (Huenneke and Mooney 1989). Although the range of California's grassland communities has changed little since European settlement more than 200 years ago, their species composition has been altered dramatically. Heavy livestock grazing, cultivation, wildfire suppression and the introduction of annual species from the Mediterranean have transformed California's oncepristine and diverse grasslands, which were dominated by perennial bunchgrasses, to invasive, annual-dominated grasslands with lower species diversity (Dyer and Rice 1997; Heady et al. 1992; Huenneke and Mooney 1989). Less than $10 \%$ of California native perennial grassland is estimated to remain (Huenneke and Mooney 1989).

The remaining perennial grasslands in California's interior are dominated by the native species purple needlegrass (Nassella pulchra [A. Hitchc.] Barkworth), blue wildrye (Elymus glaucus Buckley), bluegrass (Poa secunda J.S. Presl.), California melic (Melica californica Scribner), creeping wildrye (Leymus triticoides [Buckley] Pilger) and meadow barley (Hordeum brachyantherum Nevski) (Hickman 1993). Purple needlegrass, blue wildrye, bluegrass and California melic are droughttolerant species that typically occupy well-drained upland sites. In contrast, creeping wildrye and meadow barley are less drought-tolerant and typically grow in the moist soils of seeps, streams and wetland margins (Walker 1992; Hickman 1993). Creeping wildrye and meadow barley are also flood-tolerant.

California annual exotic grasslands are largely composed of the species Italian ryegrass (Lolium multiflorum Lam.), soft chess (Bromus hordeaceus L.), ripgut grass (Bromus diandrus Roth), wild oat (Avena fatua L.), medusahead (Taeniatherum caput-medusae [L.] Nevski) and foxtail barley (Hordeum murinum L.). Yellow starthistle (Centaurea solstitialis L.) and broadleaf filaree (Erodium botrys [Cav.] Bertol.) form a large component of the associated invasive annual broadleaf biomass (Heady et al. 1992; Lulow 2004; Pitcairn et al. 2006). Except for yellow starthistle, all of these invasive species complete their life cycles by the time soils become dry in the summer

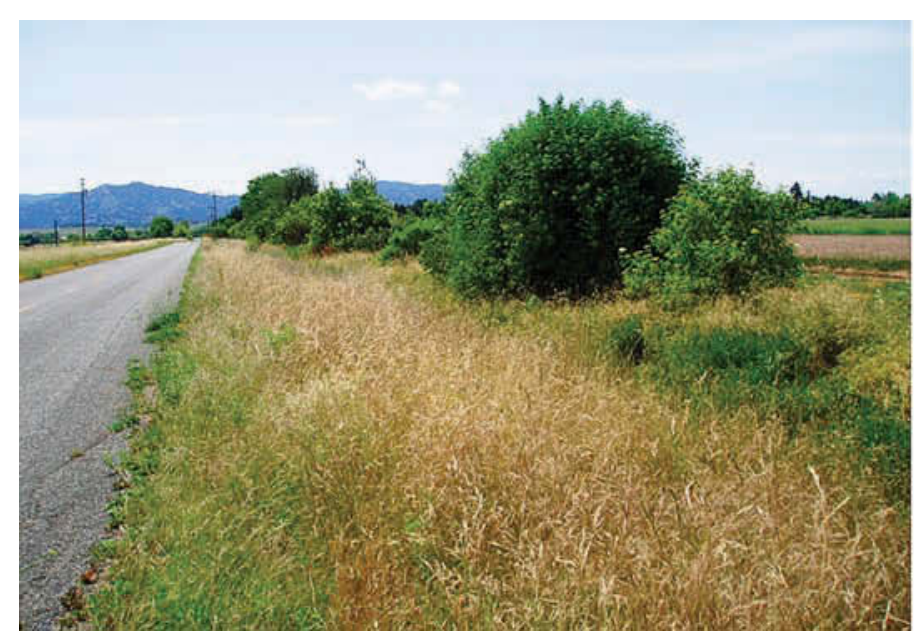

At relatively undisturbed site 1 (looking west), vegetation from the road edge (left) to swale (bottom right to center) is dominated by the native perennial purple needlegrass. The swale is periodically inundated in winter and contains a few individuals of the native perennial meadow barley distributed among a dense cover of common vetch (Vicia sativa), an invasive annual.

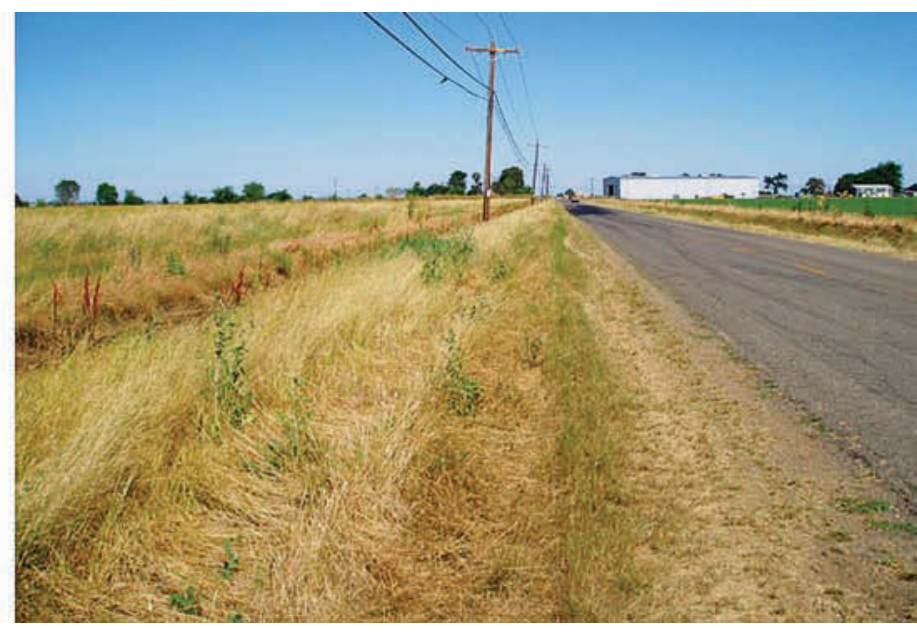

The road edge of heavily traveled site 4 (looking east) is bare (bottom right to center). A dense strip of stunted, invasive annual grasses (Italian ryegrass and foxtail barley) occurs to the left of the road edge on the shoulder (bottom center to center). A strip of the native perennial purple needlegrass occurs on the much-less-disturbed backslope (bottom left to center). 
(Huenneke and Mooney 1989). In contrast, yellow starthistle is deeply rooted, drought-tolerant and continues active growth throughout most of the growing season, until it completes its life cycle in late summer or early fall (Morghan and Rice 2005).

\section{Restoring native perennial grass}

The regeneration of native perennial grasslands is desirable to improve the quality of grazing forage; establish stable vegetative cover for soil conservation; provide habitat for wildlife; reduce fire hazards associated with thick, matted, invasive annual thatch; and suppress resident invasive annual species (Brown and Rice 2000; Bugg et al. 1997; Kemper et al. 1992). Although the establishment of native grass stands is initially labor-intensive, the long-term management time and costs required are substantially lower than that for controlling the growth and spread of noxious invasive species along roadsides, generally with intensive herbicide applications and repeated mowing (Westbrooks 1998). The cost of installing and maintaining native grassland can vary considerably from site to site. Robins et al. (2001) estimated installation costs (earthwork, tillage, herbicide, seeding) at $\$ 522$ to $\$ 1,433$ per acre of roadside, using current costs for seed; maintenance costs for each of the first 3 years of establishment were an estimated $\$ 52$ to $\$ 153$ per acre, with similar costs occurring periodically (2 to 3 years) in following years.

Early attempts to restore native perennial grasslands in annual grassdominated pasturelands were largely unsuccessful due to inadequate preparation of the soil prior to planting and suppression by competitive, invasive species after planting, as well as heavy grazing (Kay et al. 1981). Recently, the successful establishment of native perennial grasses has been attributed to preplanting site preparation, including burning to reduce invasive-species seed and thatch loads, ripping and disking to improve the seedbed, and pre-emergent and postemergent herbicide treatments to reduce residual invasive annuals (Anderson 2001; Bugg et al. 1997; Lulow 2004; Stromberg and Kephart 1996).

In their roadside perennial-grassland restoration studies, Bugg et al. (1997) described environmental gradients, particularly with respect to soil moisture across roadside topographic zones. The gradient across topographic zones creates the potential for variations in species distribution within the planting. The authors examined the distribution of native perennial grass species with respect to roadside topographic zones. Although

TABLE 1. Management practices used by landowners on roadside planting sites established by Yolo County Resource Conservation District

\begin{tabular}{|c|c|c|c|c|}
\hline Site & Established & $\begin{array}{l}\text { Mowing } \\
\text { regime }\end{array}$ & Spraying regime* & $\begin{array}{l}\text { Burning } \\
\text { regime }\end{array}$ \\
\hline 1 & 1993 & $\begin{array}{l}\text { Once } \\
\text { postplanting }\end{array}$ & $\begin{array}{l}\text { Yearly spot application chlorsulfuron, } \\
2,4-D \text { and clopyralid }\end{array}$ & Alternate years \\
\hline 2 & 1993 & $\begin{array}{l}\text { Once } \\
\text { postplanting }\end{array}$ & $\begin{array}{l}\text { Yearly spot application chlorsulfuron, } \\
\text { 2,4-D and clopyralid }\end{array}$ & Alternate years \\
\hline 3 & 1996 & Yearly & Yearly entire site application clopyralid & $\begin{array}{l}\text { Twice } \\
\text { postplanting }\end{array}$ \\
\hline 4 & 2001 & Twice yearly & None & None \\
\hline 5 & 1998 & $\begin{array}{l}\text { Twice } \\
\text { postplanting }\end{array}$ & $\begin{array}{l}\text { Alternate years entire site application } \\
\text { clopyralid, 2,4-D or bromoxynil }\end{array}$ & $\begin{array}{l}\text { Once } \\
\text { postplanting }\end{array}$ \\
\hline 6 & 1999 & Twice yearly & Yearly spot application clopyralid & None \\
\hline 7 & 2001 & Yearly & $\begin{array}{l}\text { Yearly entire site application clopyralid } \\
\text { or } 2,4-D\end{array}$ & Alternate years \\
\hline 8 & 2001 & Twice yearly & $\begin{array}{l}\text { Yearly entire site application triclopyr } \\
\text { or 2,4-D }\end{array}$ & Alternate years \\
\hline 9 & 2001 & Yearly & $\begin{array}{l}\text { One to three times yearly entire site } \\
\text { application triclopyr or 2,4-D }\end{array}$ & Alternate years \\
\hline
\end{tabular}

* Chlorsulfuron (Telar) is a preemergent herbicide that targets and inhibits seed germination and seedling establishment. Clopyralid (Transline), bromoxynil (Buctril), triclopyr (Garlon 4) and 2,4-D are postemergent broadleaf herbicides. Herbicide application varied by site and degree of invasive species cover. they predicted that the optimal environmental and tolerance features of each native California perennial grass species should result in the selective establishment of certain species within particular roadside topographic zones, their results did not reveal any such trend for 2 years after seeding.

\section{Yolo County planting history}

In 1993, the Yolo County Resource Conservation District (YCRCD) began to establish permanent, native perennial grass plantings as an alternative to managing invasive annual grass-dominated roadside rights-ofway (Rose 1998). YCRCD established 30 such plantings between 1993 and 2001 throughout Yolo County in the Sacramento Valley. Roadside and fieldside areas were required to be at least 11.5 feet (3.5 meters) wide for proper seeding and maintenance-equipment access, and to accommodate agricultural-implement turns. Sites were also required to have slopes of less than four-to-one (horizontal-to-vertical) for safety and ease of equipment operation during establishment and maintenance. The quantity and timing of runoff to roadside ditches were considered in the selection of plant species seeded at each site. The soil texture class at all sites was a silty clay loam (Andrews 1972).

All sites were lightly disked in the fall to prepare the seedbed. Before seeding each site, a single application of glyphosate (Roundup) herbicide was applied to reduce competition by invasive species with newly emerged native-grass seedlings. Each site was then seeded with purple needlegrass, blue wildrye, creeping wildrye and meadow barley at approximately 30 pounds per acre (34 kilograms per hectare) of pure live seed (Rose 1998) using precision broadcast seeders or hand-held belly grinders. An ATV pulling a straight-toothed and flexible harrow was used to incorporate the seed into the soil. Following fall planting, a selective broadleaf herbicide was applied in late winter to control broadleaf invasive species.

In the second year, landowners assumed invasive species management responsibilities, which included occasional mowing, spot treatments with herbicides to control invasive species and burning (table 1). Some owners 


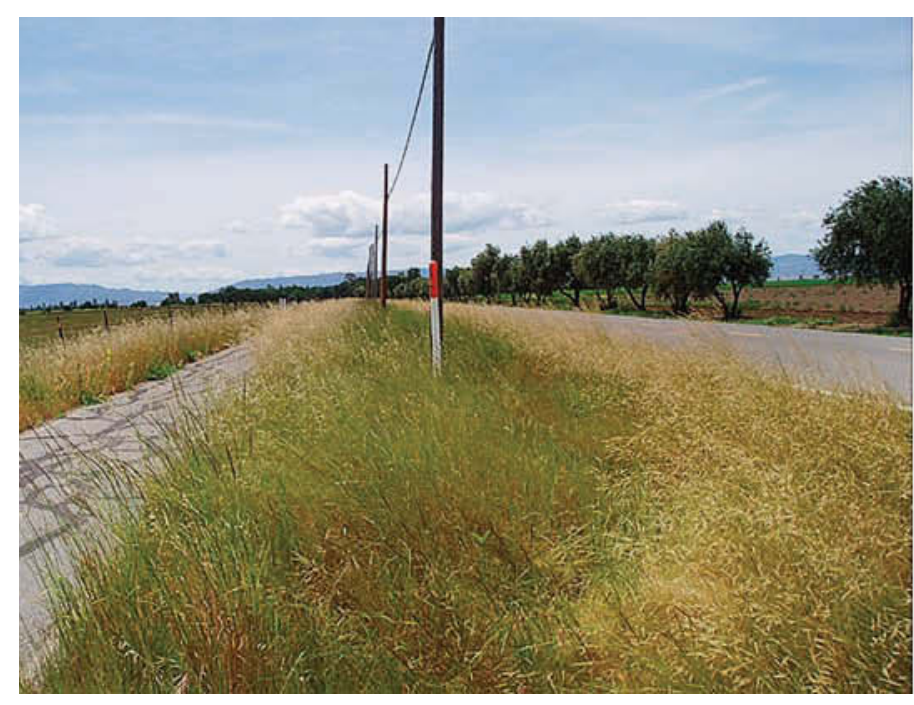

Relatively undisturbed site 9 (looking west) is bordered by a bike path (left) and road (right). Dense strips of the native perennial purple needlegrass (straw-colored inflorescences) are on the backslope (left) and shoulder (right of the phone poles), and a dense strip of the surrounding native perennial creeping wildrye (dark green) is in the swale (surrounding the phone poles).

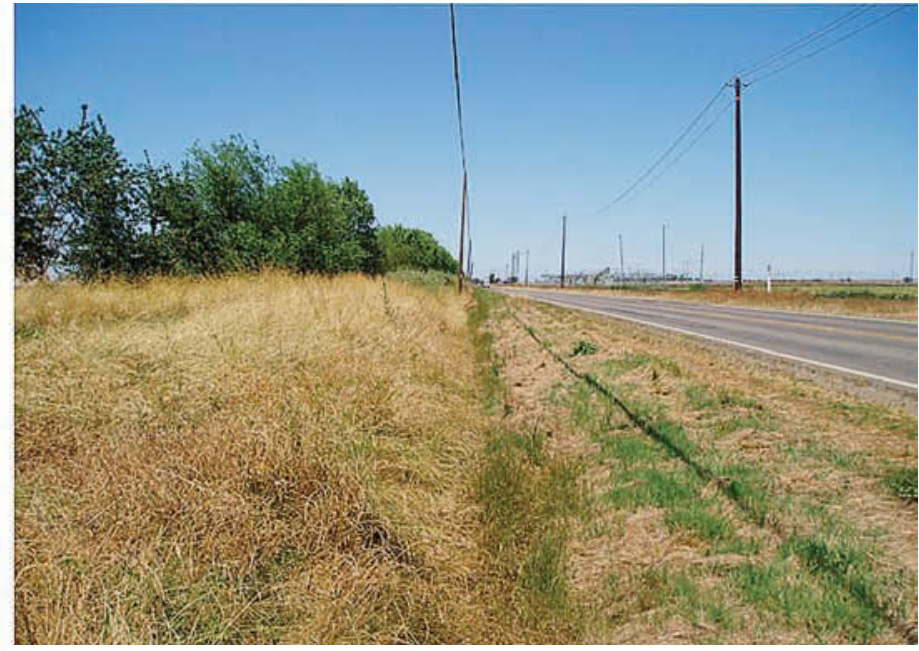

Vegetation cover on the road edge and shoulder (bottom right to center) of site 3 (looking north) is low. Low mowing on the shoulder has resulted in a monoculture stand of Bermuda grass (Cynodon dactylon), an invasive perennial. The narrow swale (bottom center to center) is dominated by Italian ryegrass, an invasive annual. Vegetation on the backslope (bottom left to center) is dominated by the native perennial purple needlegrass, with some invasive annual common vetch. chose to seed native broadleaf species into their native plantings. Those species included yarrow (Achillea millefolium), California poppy (Eschscholzia californica), gumplant (Grindelia camporum) and lupine (Lupinus sp.), which were seeded at unknown rates.

\section{Planting survey}

Although 30 YCRCD sites were established, complete records on postestablishment treatments (including herbicide treatment and burning) had been kept for only nine long-established (5 to 13 years) sites (table 2 ). We surveyed these sites in late spring 2006. We sought to determine: (1) the restoration success of matured roadside perennial grass plantings compared to adjacent unrestored roadsides, as represented by plant cover and density; (2) whether certain restoration species dominated particular roadside topographic zones (microhabitats); and (3) whether distur- bance affects the native-versus-invasive composition of the planting.

Data collection. Point-transect plant cover and species identification were collected at each of the nine sites. Topographic zones - including edge, shoulder, swale and backslope - were delineated at each site, similar to those delineated by Bugg et al. (1997) (fig. 1; table 3).

The distance of the topographic transects from the road pavement edge was dictated by each site's unique topogra-
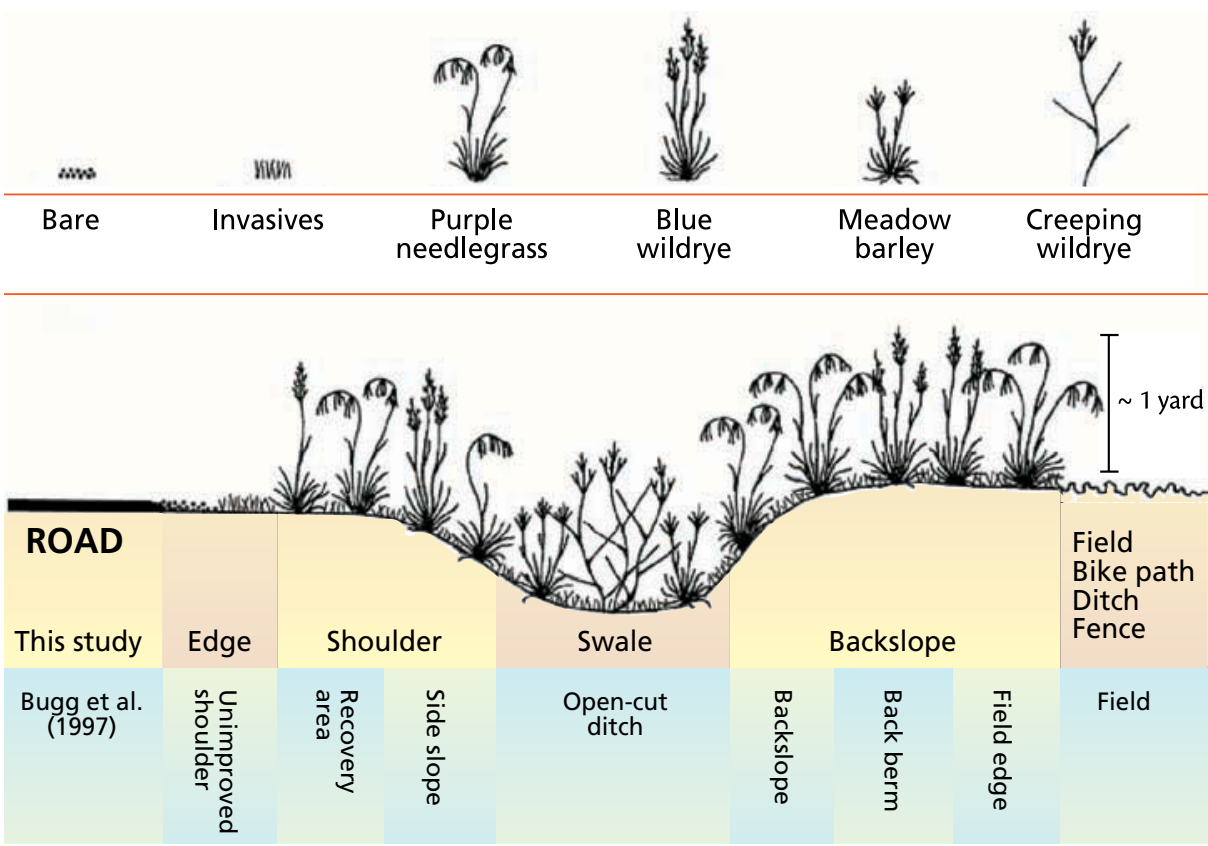

TABLE 2. Yolo County Resource Conservation District survey site locations

\begin{tabular}{cl} 
Site & Location \\
\hline 1 & $\begin{array}{l}0.5 \text { miles west of intersection of roads } 89 \\
\text { and } 27 \text { (north side of road 27) }\end{array}$ \\
2 & $\begin{array}{l}0.5 \text { miles west of intersection of roads } 89 \\
\text { and } 27 \text { (south side of road 27) }\end{array}$ \\
3 & $\begin{array}{l}1 \text { mile north of intersection of roads } 89 \\
\text { and } 23 \text { (west side of road } 89 \text { ) }\end{array}$ \\
4 & $\begin{array}{l}0.5 \text { miles west of intersection of roads } 89 \\
\text { and } 23 \text { (north side of road 23) }\end{array}$ \\
5 & $\begin{array}{l}1 \text { mile north of intersection of roads } 102 \\
\text { and } 16 \text { (east side of road 102) }\end{array}$ \\
6 & $\begin{array}{l}1 \text { mile north of intersection of roads } 89 \\
\text { and } 31 \text { (west side of road } 89 \text { ) }\end{array}$ \\
7 & $\begin{array}{l}\text { Intersection of I-505 and road 13 } \\
\text { (southwest side of intersection) }\end{array}$ \\
8 & $\begin{array}{l}1 \text { mile west of intersection of Russell } \\
\text { Blvd. (Davis) and road } 87 \text { (north side of } \\
\text { Russell Blvd.) }\end{array}$ \\
9 & $\begin{array}{l}\text { 0.5 miles west of intersection of Russell } \\
\text { Blvd. (Davis) and road } 96 \text { (south side of } \\
\text { Russell Blvd.) }\end{array}$ \\
\hline &
\end{tabular}

Fig. 1. Roadside topographic zones delineated for this study as compared to Bugg et al. (1997). The grass species distribution depicted reflects the general trends in species distribution observed at various sites. 
TABLE 3. Distribution of topographic zone-impact combinations across survey sites

\begin{tabular}{|c|c|c|c|c|c|c|c|c|c|c|c|}
\hline \multirow[b]{2}{*}{ Topograhic zone } & \multirow[b]{2}{*}{ Observed condition } & \multicolumn{9}{|c|}{ Site } & \multirow[b]{2}{*}{ No. sites } \\
\hline & & 1 & 2 & 3 & 4 & 5 & 6 & 7 & 8 & 9 & \\
\hline Edge & Heavily disturbed & & & $\mathrm{X}$ & $x$ & & & & & & 2 \\
\hline Edge & Lightly disturbed & & $x$ & & & $x$ & $x$ & $x$ & & $x$ & 5 \\
\hline Edge & Undisturbed & $x$ & & & & & & & & & 1 \\
\hline Shoulder & Heavily disturbed & & & $x$ & & & $x$ & $x$ & & & 3 \\
\hline Shoulder & Undisturbed & $x$ & $x$ & & $x$ & $x$ & & & $x$ & $x$ & 6 \\
\hline Swale & Heavily disturbed & & & $x$ & $x$ & $x$ & $x$ & & $x$ & & 5 \\
\hline Swale & Undisturbed & $x$ & & & & & & $x$ & & $x$ & 3 \\
\hline Backslope & Heavily disturbed & & & & & $x$ & & & $x$ & & 2 \\
\hline Backslope & Undisturbed & $x$ & & $x$ & & & $x$ & $\mathrm{x}$ & & $\mathrm{x}$ & 5 \\
\hline
\end{tabular}

TABLE 4. Criteria used to categorize vegetation cover in topographic zones and impacts that may have caused the condition

\begin{tabular}{|c|c|c|c|}
\hline Topographic zone & Condition & Appearance & Impact \\
\hline Edge & Heavily disturbed & $\begin{array}{l}\text { Plants nonexistent } \\
\text { (bare ground) }\end{array}$ & $\begin{array}{l}\text { Heavy travel, soil } \\
\text { disturbance, scalping, } \\
\text { herbicide }\end{array}$ \\
\hline Edge & Lightly disturbed & Plants flattened to ground & $\begin{array}{l}\text { Light travel, soil } \\
\text { disturbance, scalping, } \\
\text { herbicide }\end{array}$ \\
\hline Edge & Undisturbed & $\begin{array}{l}\text { Plants in dense stands } \\
\text { and upright }\end{array}$ & None \\
\hline Shoulder & Heavily disturbed & $\begin{array}{l}\text { Plants flattened to ground; } \\
\text { plants sparse or bare soil } \\
\text { patches }\end{array}$ & $\begin{array}{l}\text { Light travel, soil } \\
\text { disturbance, scalping, } \\
\text { herbicide }\end{array}$ \\
\hline Shoulder & Undisturbed & $\begin{array}{l}\text { Plants in dense stands and } \\
\text { upright }\end{array}$ & None \\
\hline Swale & Heavily disturbed & $\begin{array}{l}\text { Plants flattened to ground; } \\
\text { plants sparse or bare soil } \\
\text { patches }\end{array}$ & $\begin{array}{l}\text { Inundation, travel, soil } \\
\text { disturbance, scalping, } \\
\text { herbicide }\end{array}$ \\
\hline Swale & Undisturbed & $\begin{array}{l}\text { Plants in dense stands and } \\
\text { upright }\end{array}$ & None \\
\hline Backslope & Heavily disturbed & $\begin{array}{l}\text { Plants flattened to ground; } \\
\text { plants sparse or bare soil } \\
\text { patches }\end{array}$ & $\begin{array}{l}\text { Light travel, soil } \\
\text { disturbance, scalping, } \\
\text { herbicide }\end{array}$ \\
\hline Backslope & Undisturbed & $\begin{array}{l}\text { Plants in dense stands } \\
\text { and upright }\end{array}$ & None \\
\hline
\end{tabular}

TABLE 5. Effect of topographic zone-impact interactions on cover types*

\begin{tabular}{|c|c|c|c|c|c|c|}
\hline \multirow[b]{2}{*}{ Topographic zone } & \multirow[b]{2}{*}{ Condition } & \multicolumn{5}{|c|}{ Cover $t$} \\
\hline & & Bare & Invasives & PN/BW & $\mathrm{CW} / \mathrm{MB}$ & Other natives \\
\hline & & \multicolumn{5}{|c|}{ 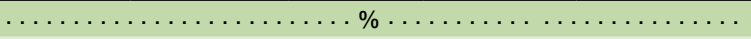 } \\
\hline Edge & $\begin{array}{l}\text { Heavily } \\
\text { disturbed }\end{array}$ & $90.7 \pm 2.9$ & $9.3 \pm 2.9$ & $0.0 \pm 0.0$ & $0.0 \pm 0.0$ & $0.0 \pm 0.0$ \\
\hline Edge & $\begin{array}{l}\text { Lightly } \\
\text { disturbed }\end{array}$ & $0.4 \pm 0.3$ & $91.4 \pm 1.5$ & $5.1 \pm 1.1$ & $0.0 \pm 0.0$ & $3.1 \pm 1.0$ \\
\hline Edge & Undisturbed & $4.5 \S$ & $39.5 \S$ & $46.0 \S$ & $0.0 \S$ & $10.0 \S$ \\
\hline Shoulder & $\begin{array}{l}\text { Heavily } \\
\text { disturbed }\end{array}$ & $8.3 \pm 1.7$ & $91.7 \pm 1.7$ & $0.0 \pm 0.0$ & $0.0 \pm 0.0$ & $0.0 \pm 0.0$ \\
\hline Shoulder & Undisturbed & $0.3 \pm 0.1$ & $22.0 \pm 4.7$ & $76.0 \pm 4.6$ & $1.1 \pm 1.1$ & $0.6 \pm 0.5$ \\
\hline Swale & $\begin{array}{l}\text { Heavily } \\
\text { disturbed }\end{array}$ & $7.5 \pm 1.9$ & $76.4 \pm 6.0$ & $3.9 \pm 2.3$ & $12.2 \pm 2.7$ & $0.0 \pm 0.0$ \\
\hline Swale & Undisturbed & $0.5 \pm 0.5$ & $44.1 \pm 5.2$ & $8.2 \pm 2.8$ & $47.0 \pm 5.3$ & $0.2 \pm 0.2$ \\
\hline Backslope & $\begin{array}{l}\text { Heavily } \\
\text { disturbed }\end{array}$ & $15.4 \pm 3.3$ & $76.0 \pm 4.0$ & $8.3 \pm 1.5$ & $0.0 \pm 0.0$ & $0.3 \pm 0.3$ \\
\hline Backslope & Undisturbed & $1.3 \pm 0.8$ & $22.5 \pm 3.3$ & $75.9 \pm 3.3$ & $0.3 \pm 0.2$ & $0.0 \pm 0.0$ \\
\hline \multicolumn{7}{|c|}{$\begin{array}{l}\text { * } n=1-6, \text { mean } \pm \text { standard error of the mean (SEM). Dominant cover types } \\
\text { for each topographic zone-impact combination are shown in red. }\end{array}$} \\
\hline \multicolumn{7}{|c|}{$\begin{array}{l}\text { + Bare, invasives, purple needlegrass/blue wildrye (PN/BW) species assemblage, } \\
\text { creeping wildrye/meadow barley (CW/MB) species assemblage, natives assemblage. }\end{array}$} \\
\hline \multicolumn{7}{|c|}{$\S$ No SEM due to only one replicate. } \\
\hline
\end{tabular}

phy and was variable between sites. Contiguous 6.56-foot (2 meter) pointtransect surveys $(\mathrm{n}=10)$ were conducted per topographic zone (edge, shoulder, swale, backslope) per site. This linear transect layout was necessary to accommodate the geometry of the roadside sites. The transect starting points were randomly selected. Such systematic sampling is regarded as analogous to simple random sampling when the population sampled is in random order (Williams 1978). Point-transect cover (bare or plant) and species identification (when plants were present) were collected at 0.33 -foot (0.1-meter) intervals (20 intervals total per 0.33-foot transect).

The same point-transect data collection method was used to collect data from the shoulder topographic zones of an unplanted roadside area adjacent to each roadside planting site (control). The disturbance condition of each topographic zone (heavily disturbed, lightly disturbed, undisturbed) was determined based on vegetation appearance and evidence of adverse impacts, including prolonged inundation, vehicle travel impact, disking, scalping/low mowing and herbicide application (table 4).

In order to examine species microhabitat preferences at each site, cover data for the drought-tolerant species, purple needlegrass (PN) and blue wildrye (BW), were combined (PN/BW) within individual topographic zones (edge, shoulder, swale, backslope), as was cover data for the droughtsusceptible species, creeping wildrye $(\mathrm{CW})$ and meadow barley (MB). Invasive and native species cover (excluding PN, $\mathrm{BW}, \mathrm{CW}$ and $\mathrm{MB}$ ) were combined into separate groups according to individual topographic zones as well; these species groups are termed assemblages.

Statistics. AR1 structure (autoregressive of order 1) analyses of errors across the contiguous transects confirmed that autocorrelation was insignificant (maximum autocorrelation estimate $=$ 0 ). Zone differences within a given assemblage were evaluated by two-way ANOVA. Mean separation between factors was established by Fisher's LSD. The significance level was set at $P=0.05$. All statistical analyses were conducted using Statistica 6.1. To examine the trend effects of disturbance on species assemblage cover, data be- 


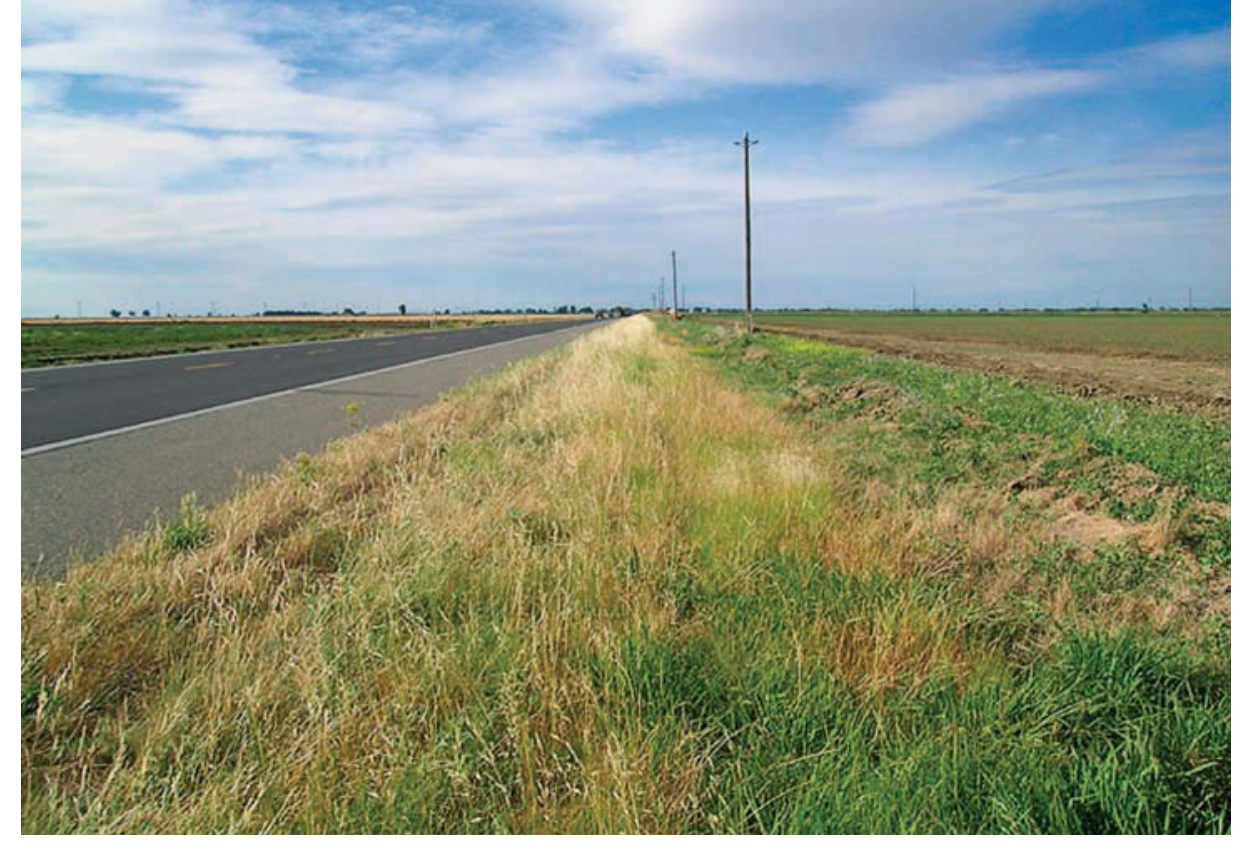

A dense strip of invasive species dominates the road edge (bottom left to center) of site 5 (looking north). The shoulder (bottom center to center) contains the native perennial purple needlegrass intermixed with Italian ryegrass and soft chess, invasive annual species. The swale and backslope (bottom right to center) have been disked (far right). The swale is periodically inundated by irrigation runoff in summer. Heavy disturbance in the swale and backslope has resulted in dominance by the invasives field bindweed, summer mustard (Hirschfeldia incanna) and wild radish (Raphanus sativus).

tween sites was grouped by condition according to topographic zone (table 5). Due to critically low replicates in some groups ( $<<3$; see table 3$)$, no statistical tests could be run using this data set, but strong trends were evident through comparison of the means.

\section{Persistence, microhabitat}

The native perennial grass species originally planted, including purple needlegrass, blue wildrye, creeping wildrye and meadow barley, continued to dominate most of the plantings more than a decade after establishment. All of the native grasses had flowered and produced a profusion of seed, much of which had fallen to the ground below the parent plants. In addition to native grasses, herbaceous broadleaf species such as yarrow, gumplant, California poppy and lupine were common among the bunchgrasses. Invasive annual and perennial species common in portions of some of the sites included Italian ryegrass, soft chess, foxtail barley, yellow starthistle and field bindweed (Convolvulus arvensis). In highly disturbed areas of the sites, a thick thatch of these invasive species had accumulated. None of the adjacent, unplanted, control roadside sites contained a single native plant.

In general, the recruitment of native perennial grasses in annual-dominated grasslands is strongly suppressed due to competition from fast-growing resident invasive annual species (Brown and Rice 2000; Dyer and Rice 1997; Dyer and Rice 1999; Hamilton et al. 1999; Lulow 2004; Seabloom et al.
2003; Stromberg and Kephart 1996). Although native California perennial grass species are effective competitors once established, they are relatively poor competitors with invasive annual species in the early stages of seedling establishment. Invasive annual grass species complete their life cycles early in the growing season (spring and early summer) by virtue of rapid growth rates, high shoot-to-root biomass allocation and the efficient production of very-fine-diameter roots to acquire water resources from the upper soil profile (Holmes and Rice 1996).

Native perennial bunchgrass species, in contrast, allocate a much greater proportion of their biomass to the production of a deep root system, in order to access deep soil moisture during the dry season. Evidence strongly suggests that competition for water between invasive annuals and native perennial grass seedlings, which are shallowrooted in their early stages of growth, limits the establishment of perennial grass seedlings on invasive, annualdominated roadsides and other annual grasslands (Dyer and Rice 1997; Dyer and Rice 1999; Hamilton et al. 1999; Holmes and Rice 1996).

Water availability is one of the most important resources that controls plant cover, composition and distribution across the landscape. Roadsides may have sharp gradients in soil-water availability associated with the sloped topography of the site. Road edge, shoulder and backslope topographic zones are typically well drained and have low soil-water availability during the summer. In contrast, swales tend to have greater soil-water availability that persists throughout the summer. Additionally, swales may be inundated for extended periods due to excessive winter precipitation or periodic summer irrigation runoff.

Site surveys in this study demonstrated that assemblages of native perennial grass species dominated particular roadside topographic positions. Cover by the drought-tolerant PN/BW species assemblage was significantly greater in shoulders and backslopes than in the road edges and swales $(P<0.001)$ (table 5). In contrast, cover by the drought-susceptible, floodtolerant CW/MB species assemblage was significantly greater in the swales than in the road edge, shoulder and

\section{None of the adjacent, unplanted, control roadside sites contained a single native plant.}

backslope zones $(P<0.001)$. Invasive species cover was significantly greater in road edges and swales than in either the shoulders or backslopes $(P<$ $0.001)$, coincident with areas that experience the greatest disturbance.

\section{Disturbance effects}

Increasing levels of disturbance tended to favor dominance by invasive species in the planting. Undisturbed road edges were dominated by native perennial grass species (table 5). 
The light disturbance of road edges resulted in dominance by invasive species, while heavy disturbance was so detrimental to plant growth that the ground was essentially bare. Disturbance had the same detrimental impact in the shoulder, swale and backslope zones as in the road edges.

Disturbance has a strong negative impact on the persistence of native perennial grasses. For example, plowing for agriculture and heavy grazing were major factors responsible for the degradation and loss of native perennial grasslands in California following European settlement (Bartolome 1981; Burcham 1957; Huenneke and Mooney 1989; Mack 1989). Disturbances detrimental to the persistence of native perennial grasses in the YCRCD roadside plantings included (impact followed by cause): prolonged inundation (winter precipitation and summer irrigation runoff, flooded more than 2 weeks); travel (vehicle drift off pavement, farm equipment); soil disturbance (roadside grading, disking); scalping (improper mowing height, less than 6 inches); and nonselective herbicide application (inadvertent or intentional, to reduce weed biomass).

\section{Managing roadway environments}

Planting and management plans should recognize the potential environmental and human impacts that may adversely affect the persistence of native grassland communities at the site. Additionally, plans should consider that each native perennial grass species has an optimal microhabitat within the roadside topography. Soil moisture availability in roadside topographic zones can vary greatly between the shoulder and backslope (drier) and swale (wetter). For example, purple needlegrass and blue wildrye are more suitable for shoulder and backslope topographic zones, due to their drought-tolerant characteristics; creeping wildrye and meadow barley are less drought- and more floodtolerant, so they are more suitable for swales. If a roadside site's local soilmoisture conditions are not known or are highly variable across the site, planting a mix of all four species in all topographic zones allows each species to establish itself in its optimal microenvironment.
Management activities that integrate multiple invasive-species control methods and reduce disturbance should be carefully considered with respect to site conditions, season, spatial application and frequency of application. Broadleaf herbicides and herbicide spot treatments shortly after planting can be beneficial to reduce competition by invasive species, but the broad use of nonselective herbicides is detrimental to native perennial grasses and should be avoided. Physical disturbances should also be avoided, including excessive travel, roadside grading, disking, and scalping due to low mowing height.

Once established, native grasslands can provide an attractive and lowermaintenance alternative to invasive annual grasslands. Native grasslands

\section{References}

Anderson J. 2001. Direct seeding of California native grasses in the Sacramento Valley and foothills. In: Robins P, Holmes RB, Laddish K (eds.). 2001. Bring Farm Edges Back to Life! Landowner Conservation Handbook. Yolo County Resource Conservation District. Woodland, CA. www.yolorcd.ca.gov. $101 \mathrm{p}$.

Andrews WF. 1972. Soil Survey of Yolo County, California. USDA, Soil Conservation Service, with UC Agricultural Experiment Station. Washington, DC. 102 p.

Bartolome JW. 1981. Stipa pulchra: A survivor from the pristine prairie. Fremontia 9:3-6.

Brown CS, Rice KJ. 2000. The mark of Zorro: Effects of the exotic annual grass Vulpia myuros on California native perennial grasses. Restor Ecol 8:10-7.

Bugg RL, Brown CS, Anderson JH. 1997. Restoring native perennial grasses to rural roadsides in the Sacramento Valley of California: Establishment and evaluation. Restor Ecol 5:214-28.

Burcham LT. 1957. California Range Land: An Historico-Ecological Study of the Range Resource of California. California Department of Natural Resources, Division of Forestry. Sacramento, CA. 261 p.

Dyer AR, Rice KJ. 1997. Intraspecific and diffuse competition: The response of Nassella pulchra in a California grassland. Ecol Appl 7:484-92.

Dyer AR, Rice KJ. 1999. Effects of competition on resource availability and growth of a California bunchgrass. Ecology 80:2697-710.

Hamilton JG, Holzapfel C, Mahall BE. 1999. Coexistence and interference between a native perennial grass and non-native annual grasses in California. Oecologia 121:518-26.

Heady HF, Bartolome JW, Pitt MD, et al. 1992. California prairie. In: Goodall DG (ed.). Ecosystems of the World 8A. Amsterdam: Elsevier. p 313-35.

Hickman JC. 1993. The Jepson Manual: Higher Plants of California. Berkeley, CA: UC Pr. 1,400 p.

Holmes TH, Rice KJ. 1996. Patterns of growth and soil-water utilization in some exotic annuals and native perennial bunchgrasses of California. Ann Bot 78:233-43.

Huenneke LF, Mooney HA. 1989. Grassland Structure and Function: California Annual Grassland. Dordrecht, Netherlands: Kluwer Acad Pub. 220 p.

Kay BL, Love RM, Slayback RD. 1981. Discussion: remain green well into the dry season (reducing fire hazards) and provide higher-quality forage and habitat for native animals. Although the efforts needed to regenerate native perennial grass communities can be intensive, this study confirms that they can persist for many years in right-of-way environments and can reduce the density of invasive annual species.

R.E. O'Dell is Restoration Ecologist, S.L. Young is Ph.D. Doctoral Candidate, and V.P. Claassen is Soil Scientist, Department of Land, Air, and Water Resources, UC Davis. This study was funded by a grant from the California Department of Transportation, RTA 65A0137. We thank John Anderson (Hedgerow Farms), Chris Rose, Jenny Drewitz and the Yolo County Resource Conservation District for providing survey-site information.

Revegetation with native grasses. I. A disappointing history. Fremontia 9:11-5.

Kemper D, Dabney S, Kramer L, et al. 1992.

Hedging against erosion. J Soil Water Conserv 47:284-8.

Lulow ME. 2004. Restoration in California's inland grasslands: The role of priority effects and management strategies in establishing native communities and the ability of native grasses to resist invasion by non-native grasses. Ph.D. dissertation, UC Davis. 101 p.

Mack RA. 1989. Temperate grasslands vulnerable to plant invasion: Characteristics and consequences. In: Drake JA, Mooney HA, DiCastri F, et al. (eds.). Biological Invasions: A Global Perspective. New York: J Wiley. 525 p.

Morghan KJR, Rice KJ. 2005. Centaurea solstitialis invasion success in influences by Nassella pulchra size. Restor Ecol 13:524-8.

Pitcairn MJ, Schoenig S, Yacoub R, Gendron J. 2006. Yellow starthistle continues its spread in California. Cal Ag 60(2):83-90.

Robins P, Holmes RB, Laddish K (eds.). 2001. Bring Farm Edges Back to Life! Landowner Conservation Handbook. Yolo County Resource Conservation District. Woodland, CA. www.yolorcd.ca.gov. 101 p.

Rose CR. 1998. Water quality and irrigation ecosystem management project: Yolo County Resource Conservation District. California State Water Resources Control Board and California Regional Water Quality Control Board, Central Valley Division. Contract No. 4-124-255-0.

Seabloom EW, Borer ET, Boucher VL, et al. 2003. Competition, seed limitation, disturbance, and reestablishment of California native annual forbs. Ecol Appl 13:575-92.

Stromberg MR, Kephart P. 1996. Restoring native grasses in California old fields. Restor Manage Notes 14:102-11.

Walker RE. 1992. Community models of species richness: Regional variation of plant community species composition on the west slope of the Sierra Nevada, California. MA thesis, UC Santa Barbara. 155 p.

Westbrooks RG. 1998. Invasive Plants: Changing the Landscape of America: Fact Book. Federal Interagency Committee for the Management of Noxious and Exotic Weeds. Washington, DC. 109 p.

Williams B. 1978. A Sampler on Sampling. New York: J Wiley. 254 p. 